
1(1), 79-96.

\title{
PERWUJUDAN INDUSTRI PARIWISATA 4.0 MELALUI IMPLEMENTASI DIGITAL TOURISM DI KOTA LHOKSEUMAWE
}

\author{
Sufi ${ }^{1)}$, Julian Sabri \\ ${ }^{1}$ Program Studi Administrasi Bisnis FISIP Universitas Malikussaleh, sufi@unimal.ac.id
}

\section{ABSTRACT}

The application of information technology in the era of the Industrial Revolution 4.0 has provided great convenience and impact on various sectors of life in a country, including the ease of promoting tourism. One of the topic that is developing in the world of modern tourism is digital tourism. The use of digital technology is one of the methods developed by the Ministry of Tourism in promoting tourism in Indonesia. This study produces an outcome regarding the implementation of local government policies in the tourism sector in Lhokseumawe City and the strategies used in promoting tourism towards the tourism era 4.0. Data collection techniques in this study by making observations (observations), interviews (interviews), and documentation. Meanwhile, data analysis techniques are carried out through data reduction, data presentation, and drawing conclusions / verification. It is hoped that the Lhokseumawe City government will cooperate with all elements of tourism actors, both private and public, so that every policy can run well and the benefits of tourism can be felt by all people.

Keywords: Implementation, Digital Tourism, Tourism

\begin{abstract}
ABSTRAK
Penerapan teknologi informasi dalam era Revolusi Industri 4.0 telah memberikan kemudahan dan dampak yang sangat besar bagi berbagai sektor kehidupan dalam sebuah negara, termasuk kemudahan dalam mempromosikan pariwisata. Salah satu topik yang berkembang dalam dunia pariwisata modern adalah digital tourism. Pemanfaatan teknologi digital ini merupakan salah satu metode yang dikembangkan oleh Kementerian Pariwisata dalam mempromosikan pariwisata di Indonesia. Penelitian ini menghasilkan luaran tentang implementasi kebijakan Pemerintah Daerah dalam bidang pariwisata di Kota Lhokseumawe dan strategi yang digunakan dalam mempromosikan pariwisata menuju era pariwisata 4.0. Teknik pengumpulan data dalam penelitian ini dengan melakukan pengamatan (observasi), wawancara (interview), dan dokumentasi. Sementara teknik analisa data dilakukan melalui reduksi data, penyajian data, dan penarikan kesimpulan/verifikasi. Diharapkan kepada pemerintah Kota Lhokseumawe agar bekerjasama dengan semua elemen pelaku pariwisata baik itu pihak swasta maupun masyarakat agar setiap kebijakan dapat berjalan dengan baik dan manfaat pariwisata dapat dirasakan oleh semua kalangan masyarakat.
\end{abstract}

Kata Kunci: Implementasi, Digital Tourism, Pariwisata 


\section{PENDAHULUAN}

Dalam era Revolusi Industri 4.0, perkembangan teknologi informasi adalah sebuah keniscayaan yang harus dihadapi. Digitalisasi menerpa seluruh aspek kehidupan, tidak terkecuali dalam dunia pemerintahan. Para pemangku kebijakan senantiasa dituntut untuk beradaptasi. Sebuah kebijakan perlu direalisasikan secara terencana agar tercapai tujuan yang diharapkan (Usman \& Nurdin, 2002). Namun dalam dunia baru ini, kebijakan tidak bisa dirumuskan secara kaku, begitu pula dalam implementasinya. Pemerintah membutuhkan metode yang tidak bersifat konvensional (biasa-biasa saja) agar mampu mengakomodasi perkembangan zaman yang serba digital tersebut. Implementasi kebijakan dibutuhkan dalam berbagai sektor pemerintahan (Nugroho, 2014). Salah satu sektor strategis yaitu pariwisata (tourism) karena menyumbang devisa yang sangat besar bagi Indonesia. Kebijakan dan implementasi kebijakan pada sektor pariwisata memerlukan perhatian serius (Prihati, 2017). Salah satu upaya yang dilakukan oleh pemerintah yaitu dengan menerapkan kebijakan digital tourism.

Pada saat ini pemerintah mulai mengimplementasikan teknologi informasi sebagai landasan utama dalam promosi pariwisata. Kebijakan digital tourism yang diinisiasi oleh Menteri Pariwisata, Arief Yahya, tampaknya mendapatkan sambutan positif dari berbagai daerah di Indonesia. Perlu dicatat bahwa kunci keberhasilan pembangunan kepariwisataan nasional tidak lepas dari peranserta seluruh pemangku kepentingan (stakeholder), dimulai dari tingkat daerah. Sektor pariwisata memang seharusnya dikembangkan dalam skala nasional oleh pemerintah daerah (Hadinoto, 1996). Namun sayangnya Kota Lhokseumawe yang merupakan salah satu daerah destinasi wisata di Aceh belum sepenuhnya menerapkan kebijakan tersebut. Padahal Kota Lhokseumawe memiliki potensi besar dalam sektor pariwisata. Beberapa destinasi wisata yang terdapat di seputaran Kota Lhokseumawe diantaranya Pulau Seumadu, Goa Jepang, Taman Ngieng Jioh, Sungai Kreung Cunda, Pantai Ujong Blang, Pantai Meuraksa, Taman Mangat Ceria (Water Boom), Waduk Jeulikat, Taman Riyadhah, Masjid Islamic Centre, Waduk Pusong, Bukit Paloh Batee, Pantai Rancung, Dermaga Pertamina Lhokseumawe, Pelabuhan Kreung Geukueh, Makam Putroe Neng, dan Museum Lhokseumawe.

Namun potensi pariwisata tersebut belum sepenuhnya dioptimalkan pengelolaannya oleh Pemerintah Kota Lhokseumawe. Hingga tahun 2020, belum tampak upaya serius yang dilakukan oleh Pemerintah Kota Lhokseumawe dalam menerapkan konsep digital tourism. Padahal media digital memiliki peranan yang sangat penting dalam mempengaruhi perkembangan promosi pariwisata. Bila dibandingkan dengan daerah tetangga seperti Kabupaten Aceh Tengah, promosi pariwisata berbasis digital di Kota Lhokseumawe sedikit tertinggal. Hal ini tidak sesuai harapan 
karena citra Lhokseumawe sebagai sebuah kota seharusnya lebih maju dalam pemanfaatan teknologi informasi dibandingkan dengan Kabupaten Aceh Tengah yang dominan di sektor perkebunan atau daerah Sabang yang minim penduduk (BPS, 2017). Akan tetapi, bertolakbelakang dengan Kota Lhokseumawe, kedua daerah tersebut sudah sangat gencar dalam mempromosikan pariwisata secara digital sejak beberapa tahun yang lalu. Hal tersebut dibuktikan dengan diperolehnya penghargaan dari WTO (World Tourism Organization) pada tahun 2016 berkat pemerintah lokal dan masyakarat bahu-membahu dalam mendukung pariwisatanya dengan vote melalui situs http://bit.ly/voteaceh

Tabel 1. Daerah yang Berhasil Mendapat Penghargaan

\begin{tabular}{|c|l|}
\hline No & \multicolumn{1}{|c|}{ Tempat Pariwisata } \\
\hline 1 & Aceh Menjadi The World's Best Halal Cultural Destination \\
\hline 2 & Sabang Menjadi The World's Best Marine Tourism Destination \\
\hline 3 & Danau Laut Tawar Menjadi The World's Best Adventure Destination \\
\hline
\end{tabular}

Sumber : Kemenpar RI, 2016.

Masalah tidak optimalnya implementasi digital tourim di Kota Lhokseumawe ini tentunya tidak lepas dari masih minimnya promosi pariwisata secara digital di Kota Lhokseumawe sehingga tidak satupun masuk dalam daftar penghargaan tersebut. Realitas ini dicerminkan pada tabel berikut:

Tabel 2. Daftar Media Digital yang digunakan oleh Dinas Pariwisata

\begin{tabular}{|c|l|c|c|}
\hline No & \multicolumn{1}{|c|}{ Media Digital } & Digunakan/Tidak $(\sqrt{ } / \mathbf{x})$ & Persentasi Keefektifan \\
\hline 1. & Website & $\boldsymbol{x}$ & $49 \%$ \\
\hline 2. & YouTube & $\checkmark$ & $43 \%$ \\
\hline 3. & Facebook & $\mathbf{x}$ & $41 \%$ \\
\hline 4. & Whatsapp & $\checkmark$ & $40 \%$ \\
\hline 5. & Instagram & $\mathbf{x}$ & $38 \%$ \\
\hline 6. & Line & $\mathbf{x}$ & $33 \%$ \\
\hline 7. & BBM & $\mathbf{x}$ & $28 \%$ \\
\hline 8. & Twitter & $\mathbf{x}$ & $27 \%$ \\
\hline 9. & Google+ & $\mathbf{x}$ & $25 \%$ \\
\hline 10. & FB Messenger & $\mathbf{x}$ & $24 \%$ \\
\hline 11. & LinkedIn & $\mathbf{x}$ & $16 \%$ \\
\hline 12. & Skype & $\mathbf{x}$ & $15 \%$ \\
\hline 13. & WeChat & & $14 \%$ \\
\hline
\end{tabular}

Sumber : Disporapar Kota Lhokseumawe dan WeAreSocial.Net, 2017.

81 Jurnal Ilmu Sosial dan Ilmu Politik Malikussaleh (JSPM) Volume 1 Nomor 1 Tahun 2020 
Permasalahan implementasi media digital yang ada di Kota Lhokseumawe juga dapat kita amati dari website Dinas Pemuda Olahraga dan Pariwisata Kota Lhokseumawe yaitu http://Disporapar.com./. Penulis memperoleh temuan bahwa informasi tentang objek wisata sudah lama vakum sejak 15 Agustus 2017 dan baru kembali memperbaharui informasi objek wisata pada 21 Februari 2019. Tentu saja hal itu membuat para calon wisatawan tidak mendapatkan informasi update melalui media digital. Akun sosial media yang dimiliki Disporapar Kota Lhokseumawe pun tergolong tidak aktif dimana terakhir sekali meng-update informasi wisata pada Oktober 2018. Sungguh disayangkan, penggunaan teknologi digital sangat minim diaplikasikan oleh Pemerintah Kota Lhokseumawe, padahal perkembangan di era Revolusi Pariwisata 4.0 menuntut setiap aktor yang berperan dalam pengembangan pariwisata untuk mumpuni dalam penggunaan teknologi serta mampu memanfaatkan media digital dalam memaksimalkan potensi pariwisata yang ada di setiap daerahnya.

\section{Industri Pariwisata, Digital Tourism, dan Pariwisata 4.0}

Menurut Undang-Undang Nomor 10 Tahun 2009 tentang Pariwisata bahwa industri pariwisata adalah kumpulan usaha pariwisata yang saling terkait dalam rangka menghasilkan barang dan/atau jasa bagi pemenuhan kebutuhan wisatawan dalam penyelenggaraan pariwisata. Kebutuhan ini terkait erat dengan perjalanan, rekreasi, dan waktu luang (Nurhidayati \& Fandeli, 2012) sehingga membentuk suatu industri pariwisata. Menurut Pitana (2009), sistem pariwisata terdiri dari tujuh komponen besar yang memerlukan keterkaitan, ketergantungan, dan keterpaduan, diantaranya 1) sektor pemasaran; 2) sektor perhubungan; 3) sektor akomodasi; 4) sektor daya tarik/ atraksi wisata; 5) sektor paket perjalanan; 6) sektor pendukung/rupa-rupa; dan 7) sektor pengkoordinasi atau regulator.

Adapun digital tourism adalah strategi pengembangan pariwisata dengan memanfaatkan media digital secara masif. Studi Isnaini \& Fauziyyah (2017) menunjukkan bahwa digital marketing mampu meningkatkan brand atau citra pariwisata. Strategi ini kemudian diinisiasi oleh Kementerian Pariwisata (Kemenpar) dengan tujuan mencapai target utama nasional yaitu 20 juta wisatawan mancanegara (wisman). Digital tourism bisa dilihat sebagai bentuk upaya pemerintah dalam menyesuaikan kondisi pasar yang sudah berubah. Sebab saat ini wisatawan melakukan perjalanan mulai dari mencari dan melihat-lihat informasi (look), kemudian memesan paket wisata yang diminati (book) hingga membayar secara online. Dengan kata lain, wisman era kekinian melakukan search and share menggunakan media digital. 
Pemanfaatan digital tourism tidak terlepas dari paradigma baru dalam industri pariwisata yakni konsep Pariwisata 4.0 dengan target utama wisatawan milenial. Ciri utama strategi ini adalah terbangunnya ekosistem digital sehingga mampu mendongkrak produktivitas industri pariwisata secara drastis. Optimalisasinya dapat dilakukan dengan pemanfaatan jasa endorser (Wicaksono \& Yunitasari, 2018) atau penggunaan media sosial oleh digital native (Supratman, 2018). Hal ini tampaknya berhasil diwujudkan di beberapa situs cagar budaya di Indonesia (Ri'aeni, 2015).

\section{METODE PENELITIAN}

Penelitian ini dilakukan di Kantor Dinas Pemuda, Olahraga, dan Pariwisata Kota Lhokseumawe. Pendekatan penelitian yang digunakan dalam penelitian ini adalah tipe desktriptif dengan analisa kualitatif, dengan maksud untuk memperoleh gambaran umum variabel penelitian (Sugiyono, 2009; Umar, 2014), khususnya mengenai kebijakan Pemerintah Daerah dalam mengembangkan pariwisata di Kota Lhokseumawe. Data yang diperoleh dari fenomena yang diteliti diuraikan sedemikian rupa agar mudah dipahami (Hasan, 2001). Informan ditentukan secara purposif diantaranya:

1. Kepala Dinas Pemuda, Olahraga, dan Pariwisata Kota Lhokseumawe

2. Kepala Bidang Pariwisata Dinas Pemuda, Olahraga, dan Pariwisata Kota Lhokseumawe

3. Kasi Promosi Pariwisata Dinas Pemuda, Olahraga, dan Pariwisata Kota Lhokseumawe

4. Staf Dinas Pemuda, Olahraga, dan Pariwisata Kota Lhokseumawe

5. Masyarakat Kota Lhokseumawe

Ada dua jenis sumber data yang digunakan dalam penelitian ini, yaitu data primer (observasi dan wawancara) dan data sekunder (sumber kepustakaan dan laporan resmi dari instansi terkait). Penelitian ini menggunakan beberapa teknik pengumpulan data, yaitu pengamatan, interview, dan dokumentasi. Dalam melakukan analisis data, penulis menggunakan model analisis kualitatif secara interaktif melalui 3 tahap, yaitu reduksi data, data display, dan conclusion drawing.

\section{HASIL DAN PEMBAHASAN}

\section{Regulasi dan Implementasi Promosi Pariwisata secara Digital Tourism}

Dalam rangka menerapkan sistem promosi pariwisata yang berbasis digitalisasi atau yang biasa disebut dengan digital tourism di Kota Lhokseumawe tentunya membutuhkan sebuah regulasi. Hal ini nantinya dirumuskan bukan hanya menjadi tanggung jawab pemerintah, melainkan tanggung jawab setiap elemen masyarakat karena sektor pariwisata diharapkan dapat meningkatkan perekonomian. Setiap elemen masyarakat harus berusaha untuk mempromosikan 
potensi pariwisata sesuai dengan kapasitasnya masing-masing (Mulyanto, 2007). Dalam hal ini Pemerintah Kota Lhokseumawe mengacu pada Qanun Aceh Nomor 8 Tahun 2013 tentang Kepariwisataan. Aturan ini sebagai payung hukum yang memperkuat penerapan digital tourism di Kota Lhokseumawe. Menurut Kepala Disporapar Kota Lhokseumawe:

"Sebagai tanggung jawab pemerintah dalam mempromosikan pariwisata di Kota Lhokseumawe... melalui berbagai cara termasuk secara digitalisasi... maka pemerintah Kota Lhokseumawe mengacu kepada kebijakan yang menurut pemerintah bisa mengoptimalkan promosi pariwisata dan masyarakat juga bisa ikut mempromosikan potensi pariwisata dengan aturan yang ada, dimana Pemerintah Kota Lhokseumawe mengacu pada Qanun Aceh Nomor 8 Tahun 2013 tentang Kepariwisataan. Lhokseumawe sudah mulai berbenah dan mulai mempromosikan pariwisata secara digitalisasi walaupun belum secara menyeluruh mengingat bahwa pada saat ini belum ada Qanun daerah yang mengatur tentang penerapan digital tourism di Kota Lhokseumawe”. (Zulkifli, M.Pd, Disporapar Kota Lhokseumawe, 21/06/2019)

Berdasarkan hasil wawancara di atas diperoleh gambaran bahwa aturan yang digunakan saat ini masih mengacu kepada Qanun Aceh yang dikarenakan belum adanya peraturan daerah yang secara khusus (spesifik) mengatur tentang penerapan digital tourism. Jika belum bisa dioptimalkan penerapannya dalam mempromosikan pariwisata, maka dibutuhkan berbagai kebijakan yang bisa memberikan solusi atas permasalahan tersebut. Kepala Disporapar Kota Lhokseumawe mengatakan:

"Belum terealisasinya penerapan digital tourism secara optimal adalah salah satu masalah yang harus kita selesaikan secara bersama mengingat bahwa ini adalah tugas kita bersama, termasuk masyarakat dan semua pihak yang terlibat dalam pelaku pariwisata. Namun Disporapar terus melakukan upaya dalam meng-upgrade perkembangan yang terjadi khususnya dalam era menuju pariwisata 4.0 mengingat bahwa beberapa daerah juga sudah mulai secara perlahan mempersiapkan diri menerapkan digital tourism". (Zulkifli, M.Pd, Disporapar Kota Lhokseumawe, 21/06/2019)

Udoji dalam Agustino (2012) menyebutkan pelaksanaan kebijakan adalah suatu hal yang penting bahkan mungkin jauh lebih penting daripada pembuatan kebijakan. Pelibatan masyarakat dalam promosi pariwisata merupakan bagian dari pelaksanaan kebijakan. Hal ini diamini oleh Kabid Pariwisata Disporapar Kota Lhokseumawe sebagaimana kutipan pernyataan berikut ini:

"Masalah penerapan digital tourism ini memang diberikan wewenang secara khusus dan tanggung jawab ini ada pada Disporapar Kota Lhokseumawe. Namun secara keseluruhan tanggung jawab ini bukan terletak pada Pemerintah Kota dan Disporapar saja, masyarakat juga punya tanggung jawab misalnya yang sangat sederhana yaitu penggunaan media sosial dengan konten pariwisata. Apalagi anak muda punya cara yang sangat persuasif dalam membuat konten foto menarik yang akan diunggah di sosial media sehingga ini akan menjadi salah satu cara sederhana yang dapat dilakukan dalam penerapan promosi secara digitalisasi. Namun bukan berarti di duinia nyata kita lupakan, masyakarat juga harus terbuka dan bersikap ramah kepada para wisatawan sehingga meninggalkan kesan yang

84 | Jurnal Ilmu Sosial dan Ilmu Politik Malikussaleh (JSPM) Volume 1 Nomor 1 Tahun 2020 
baik dan akhirnya ada promosi dari mulut... artinya tanggung jawab ini harus ada perpaduan antara Pemerintah Kota, Disporapar, dan masyarakat. Kalau hanya pemerintah Kota dan Disporapar saja yang bertanggung jawab terhadap promosi pariwisata apalagi secara digitalisasi tidak akan berjalan tanpa adanya partisipasi dari masyarakat". (Diana Rosa, ST, Disporapar Kota Lhokseumawe, 21/06/2019)

\section{a. Sosialisasi kepada Masyarakat}

Sosialisasi kepada masyarakat adalah suatu kebijakan yang dilakukan Disporapar dalam meningkatkan sadar wisata masyarakat. Melalui kegiatan ini diharapkan seluruh elemen masyakarat ikut mendukung segala kegiatan pariwisata baik dalam rangka promosi pariwisata maupun berbagai agenda pariwisata yang dilaksanakan di Kota Lhokseumawe. Hal ini dalam rangka mewujudkan perekonomian masyakarat yang lebih baik lagi dari sektor pariwisata. Menurut Kepala Disporapar Kota Lhokseumawe:

"... Penerapan digital tourism di Kota Lhokseumawe dilakukan dengan dua cara, baik secara langsung dilakukan oleh Dinas setiap ada agenda pariwisata seperti Aceh Fest Rapa'i Internaional langsung dipublikasikan dengan media yang ada dan setiap potensi pariwisata juga dipromosikan melalui berbagai media seperti website resmi Disporapar dan instagram yang pada dasarnya sudah berbasis digitalisasi... dan cara yang kedua yaitu secara sosialisasi melalui berbagai kegiatan pariwisata seperti Aksi Sapta Pesona di Pantai Ujong Blang yang langsung dihadiri dari pemateri dari Kemenpar. Disporapar juga sudah menyelenggarakan kegiatan pelatihan pariwisata bagi generasi milenial yang banyak menggunakan digital sebagai akses komunikasi sehari-hari, juga semua pelaku pariwisata seperti komunitas guide dan pecinta fotografi yang pada dasarnya mereka banyak melakukan interaksi di dunia digital sehingga diharapkan makin bayak pihak yang akan mendukung dan siap atas penerapan digital tourism menuju era pariwisata 4.0". (Zulkifli, M.Pd, Disporapar Kota Lhokseumawe, 21/06/2019)

Berdasarkan pendapat yang dijelaskan di atas dapat dipahami bahwa Disporapar Kota Lhokseumawe tidak hanya melakukan kegiatan sosialisasi, melainkan juga kegiatan pelatihan. Kasi Promosi Kepariwisataan Disporapar Kota Lhokseumawe mengatakan:

“... Dalam rangka penerapan digital tourism dan promosi pariwisata secara digitalisasi memang kita terapkan secara langsung oleh Dinas berupa publikasi dan promosi mealui media yang ada seperti website dan instagram. Namun kita juga melakukan sosialisasi langsung kepada masyarakat berupa Aksi Sapta Pesona dan Pelatihan Pariwisata langsung dilakukan oleh Disporapar dengan target masyarakat agar masyarakat juga siap dan menjadi support system dalam penerapan digital tourism di Kota Lhokseumawe... upaya ini sangat diperlukan mengingat bahwa kita sedang menuju era pariwisata 4.0". (Zul Afrizal, MA, Disporapar Kota Lhokseumawe, 22/06/2019)

Dijelaskan oleh Uli selaku masyarakat Kota Lhokeumawe yang mendapat pelatihan pariwisata dari Disporapar Kota Lhokseumawe: 
“...Penerapan digital tourism memang sudah ada sosialisasi dari Disporapar, tapi dalam proses sosialisasi itu masih ada kekurangan yaitu pelatihan tidak ada keberlanjutan. Pelatihan hanya dilakukan selama dua hari dan sampai saat ini belum ada kabar tentang keberlanjutan pelatihan ini. Menurut saya seharusnya ada keberlanjutan pelatihan agar ilmu yang sudah didapatkan dapat dievaluasi bersama, tetapi saya sangat mengapresiasi usaha dari Disporapar untuk melakukan pelatihan ini karena berdampak positif terhadap cara promosi kami selama ini yang manual menjadi digitalisasi dan saya juga berharap akan ada pelatihan pariwisata berbasis digitalisasi untuk selanjutnya agar seluruh lapisan masyakarat menerima dan siap untuk cara menerapkan cara promosi yang terus berkembang". (Uli, Kota Lhokseumawe, 22/06/2019)

Berdasarkan hasil deskripsi di atas dapat dipahami bahwa sosialisasi merupakan hal yang sangat penting dikarenakan masyakarat juga perlu memperoleh edukasi tentang promosi pariwisata berbasis digitalisasi agar siap untuk menghadapi perkembangan zaman dan mendukung perkembangan sektor pariwisata daerah. Hal ini sebagaimana diungkapkan oleh Kepala Disporapar Kota Lhokseumawe:

“...Kota Lhokseumawe punya potensi besar dari sektor pariwisata, karena sektor pariwisata bersifat fleksibel dan mudah mengikuti perkembangan zaman... selama positif kita akan terus dukung, apalagi jika masyakarat antuasis mengikuti berbagai pelatihan yang diberikan... tentunya ini akan mewujudkan semua elemen yang siap... apalagi jika pelatihan ini membawa kehidupan pariwisata yang benar-benar diterapkan secara digital seperti ada masyarakat yang sudah sadar akan manfaat pariwisata lalu membuat homestay dan mempromosikannya melalui aplikasi Airy dan sebagainya... tentu ini akan menarik dikarenakan di Aceh masih jarang dan di Lhokseumawe belum ada, dan memberikan dampak positif bagi sektor pariwisata dan perekonomian masyarakat yang diuntungkan karena proses digitalisasi”. (Zulkifli, M.Pd, Disporapar Kota Lhokseumawe, 21/06/2019)

Berdasarkan wawancara di atas dapat dideskripsikan bahwa sosialisasi memang sangat dibutuhkan dalam proses pelaksanaan suatu kebijakan. Kesadaran masyarakat akan manfaat pariwisata secara digitalisasi akan memberikan dampak positif terhadap sektor perekoniman dan pariwisata Kota Lhokseumawe.

\section{b. Aceh International Rafa'i Festival (ACIRAF)}

Aceh International Rafa'i Festival (ACIRAF) merupakan event bertaraf internasional yang diselenggarakan oleh Kementerian Pariwisata Republik Indonesia bekerjasama dengan Disbudpar Aceh dan Disporapar Kota Lhokseumawe sebagai bagian dari Program Wonderfull Indonesia dengan target mendatangkan wisatawan asing ke Indonesia. Aceh International Rafa'i Festival (ACIRAF) ini memiliki berbagai rangkain kegiatan mulai dari: Rafa'i International Concert, Rafa'i Street Art, Meet and Great, Jeuleukat Field Trip, dan Aceh Culture Expo. Dengan adanya event berskala internasional tentu akan berdampak positif terhadap sektor pariwisata di Kota 
Lhokseumawe. Event ini juga akan memperkenalkan budaya dan potensi pariwisata yang ada di Kota Lhokseumawe. Menurut Kepala Disporapar Kota Lhokseumawe:

“.... Aceh International Rafa'i Festival (ACIRAF) sangat menguntungkan bagi Kota Lhokseumawe karena mendatangkan banyak wisatawan baik dari nasional maupun internasional sebagai upaya dalam menuju era pariwisata $4.0 \ldots$ kegiatan ini diikuti oleh peserta mancanegara seperti Turki, India, Malaysia, dan Thailand... tentu ini akan menjadi salah satu event yang akan disorot media, terutama media dari luar dan pariwisata kita sangat terbantu karena secara tidak langsung dipromosikan secara digitalisasi oleh media baik dalam maupun luar negeri... dan tentunya akan banyak masyarakat luar yang mengetahui Kota Lhokseumawe dan ingin berkunjung ke Kota Lhokseumawe... semoga segala fasilitas pariwisata juga dapat didukung peningkatannya oleh berbagai pihak dengan event seperti ini". (Zulkifli, M.Pd, Disporapar Kota Lhokseumawe, 21/06/2019)

\section{Hambatan Implementasi Promosi Digital Tourism di Kota Lhokseumawe}

\section{a. Komunikasi}

Segala macam proses kebijakan tidak terlepas dari aspek komunikasi. Komunikasi merupakan proses penyampaian informasi dari komunikator kepada komunikan. Sementara itu, komunikasi dalam kebijakan berarti merupakan proses penyampaian informasi dari pembuat kebijakan kepada pelaksana kebijakan. Menurut Kepala Disporapar Kota Lhokseumawe:

“... Dalam hal pelaksanaan pariwisata kita tidak terlepas dari proses komunikasi baik secara internal maupun eksternal. Hal ini kami lakukan agar tidak terjadi salah paham dalam prosesnya. Komunikasi dalam instansi kami bersifat top down agar memudahkan proses penyampaian informasi sehingga informasi mengenai Peraturan yang ada di Qanun Aceh Nomor 8 Tahun 2013 tentang Kepariwisataan dapat tersampaikan dengan baik". (Zulkifli, M.Pd, Disporapar Kota Lhokseumawe, 21/06/2019)

Hal ini senada disampaikan oleh Kabid Pariwisata Disporapar Kota Lhokseumawe yang mengatakan bahwa:

"Dalam rangka terlaksananya pelaksanaan Qanun Nomor 8 Tahun 2013 tentang Kepariwisataan kami di lingkungan Disporapar Kota Lhokseumawe sangat mengutamakan komunikasi yang baik agar informasi dapat ditangkap dan dilaksanakan di lingkungan Disporapar. Selain itu juga dalam proses komunikasi saya sebagai Kabid Pariwisata juga memberikan arahan kepada teman-teman di bawah struktur termasuk penerapan digital tourism dan promosi secara digitalisasi agar melaksanakan tugas sesuai tupoksi dan peraturan yang berlaku serta memperhatikan instruksi dari Kepala Dinas secara berkelanjutan”. (Diana Rosa, ST, Disporapar Kota Lhokseumawe, 21/06/2019)

Namun keterangan yang disampaikan di atas dibantah oleh salah seorang pegiat pariwisata di Kota Lhokseumawe melalui pernyataan berikut:

"Dalam hal komunikasi antara Disporapar Kota Lhokseumawe dan masyarakat penggiat pariwisata belum sepenuhnya bisa saya katakan berjalan dengan baik, apalagi tentang penerapan Digital Tourism saya baru mengetahuinya, walaupun promosi pariwisata scara 
digital memang sudah ada saat ini, Dinas memang pernah mengadakan kegiatan Pariwisata dan sosialisasi di Pantai Ujong Blang ini namun belum ada komunikasi lanjutan”. (Vivi Anggraini, Kota Lhokseumawe, 25/06/2019)

Dengan demikian dari hasil wawancara diatas dapat dipahami bahwa penerapan digital tourism dan promosi pariwisata secara digitalisasi belum optimal. Dalam hal ini tentunya diperlukan komunikasi yang baik sehingga tujuan dari sebuah kebijakan dapat diaktualisasikan oleh semua elemen masyarakat sehingga tidak hanya terjalin secara internal tetapi juga eksternal pelaksana kebijakan.

\section{b. Sumber Daya (Resources)}

Dalam pelaksanaan sebuah kebijakan dalam rangka mencapai tujuan yang diharapkan ada banyak hal yang perlu dilakukan, salah satunya ialah sumber daya. Betapa pun jelas dan konsistennya ketentuan-ketentuan atau aturan-aturan dalam sebuah kebijakan, tanpa adanya faktor sumber daya dipastikan pelaksanaan kebijakan tersebut tidak efektif. Menurut informan penelitian yang menjabat Kepala KPw Bank Indonesia Lhokseumawe, masih banyak permasalahan dalam pengembangan pariwisata di Kota Lhokseumawe, sebagaimana diutarakan:

“Akses pendukung yang kurang, minimnya sumber daya manusia pengelola pariwisata yang profesional, banyak tempat yang dikelola sendiri oleh masyarakat merupakan beberapa permasalahan dalam pengembangan pariwisata di Kota Lhokseumawe”. (Yukon Afrinaldo, Kota Lhokseumawe, 14/06/2019).

Keberhasilan sebuah kebijakan tidak akan berhasil tanpa adanya dukungan dari sumber daya manusia yang baik dari segi kualitas dan kuantitas. Kepala Disporapar Kota Lhokseumawe menyampaikan:

“... Menanggapi hal yang berkaitan dengan sumber daya manusia kami perlu memperhatikan kualitas yang kami miliki. Dalam Disporapar Kota Lhokseumawe ini sebenarnya masih perlu pembenahan dan pembekalan. Oleh sebab itu, dari kemampuan pegawai kami untuk memaksimalkan mutu, kami mengadakan pembinaan dan pembekalan kepada pegawai kami termasuk kedepannya mungkin akan ada pembinaan dan pembekalan kemampuan dalam penerapan digital tourism sehingga diharapkan pegawai di lingkungan Disporapar mengerti betul tupoksi dan memaksimalkan peran dan fungsinya dengan baik". (Zulkifli, M.Pd, Disporapar Kota Lhokseumawe, 21/06/2019)

\section{c. Anggaran}

Salah satu faktor pendukung kesuksesan sebuah kebijakan yaitu ketersediaan anggaran. Kebijakan digital tourism tidak akan berjalan dengan efekif dalam mencapai tujuan dan sasaran 
yang diharapkan tanpa didukung oleh anggaran yang memadai. Kepala Disporapar Kota Lhokseumawe menanggapi:

".... kami sadar betul bahwa anggaran memilliki fungsi yang sangat penting berkenaan dengan pelaksanaan kebijakan tersebut, apalagi berkaitan dengan promosi pariwisata kami tentunya selalu difasilitasi dengan anggaran yang telah diplotkan. Namun jumlahnya tersebut bersifat fluktuatif sesuai dengan kebutuhan, apalagi untuk saat ini tidak ada plot anggaran khusus dalam penerapan digital tourism di Kota Lhokseumawe". (Zulkifli, M.Pd, Disporapar Kota Lhokseumawe, 21/06/2019)

Berdasarkan hasil wawancara singkat di atas dapat dipaparkan bahwa Disporapar Kota Lhokseumawe setiap tahunnya menerima kucuran dana dari pemerintah setempat. Jumlah anggaran yang diterima Disporapar berubah-ubah setiap tahunnya, tergantung kebutuhan Disporapar itu sendiri. Selanjutnya hasil wawancara Kepala Subbagian Perencanaan dan Keuangan diperoleh keterangan sebagai berikut:

“... Dana yang diterima oleh Disporapar Kota Lhokseumawe dialokasikan ke berbagai tempat, diantaranya Bidang Kepemudaan, Bidang Olahraga dan Bidang Pariwisata”. (Nina Zahara, Disporapar Kota Lhokseumawe, 21/06/2019)

Dengan adanya anggaran dalam pelaksanaann sebuah kebijakan diharapkan mampu memberikan pengaruh besar dalam kesuksesan pencapaian tujuan suatu kebijakan. Namun hal ini tergantung pula pada cara pemanfaatannya.

\section{d. Fasilitas}

Dalam pelaksanaan sebuah kebijakan, unsur fasilitas memiliki peranan yang sangat krusial. Dukungan fasilitas diharapkan membuat sebuah kebijakan terlaksana dengan baik. Hal ini sebagaimana disuarakan oleh Kabid Pariwisata Disporapar Kota Lhokseumawe sebagaimana petikan wawancara berikut:

“... Pelaksanaan Peraturan Pemerintah di kantor Disporapar ini sendiri didukung oleh fasitlitas yang telah tersedia sebelumnya. Termasuk untuk promosi secara digitalisasi meski masih minim karena masih terbatas pada akses internet dan perangkat komputer saja... untuk benar-benar menerapkan digital tourism kita membutuhkan kelengkapan alat yang lebih memadai dan sesuai standar agar kebijakan dapat optimal." (Diana Rosa, ST, Disporapar Kota Lhokseumawe, 21/06/2019)

Dari hasil pemahaman diatas dapat kita pahami bahwa fasilitas mempunyai peran yang cukup signifikan terhadap kelancaran suatu pelaksanaan kebijakan dengan adanya fasilitas yang berkaitan dan memenuhi standar tentunya pelaksanaan kebijakan akan lebih maksimal dan optimal dan tujuan kebijakan tersebut dapat disalurkan secara terarah dan penerapan kebijakan tersebut dapat terlaksana dengan baik. 


\section{e. Informasi dan Kewenangan}

Informasi menjadi suatu faktor penting dalam pelaksanaan sebuah kebijakan. Hal demikian juga berlaku pada perihal wewenang. Kewenangan berperan penting untuk menjamin bahwa kebijakan yang dilaksanakan sesuai dengan aturan yang berlaku. Kepala Sub Bagian Umum dan Kepegawaian Disporapar Kota Lhokseumawe mengutarakan:

“.... Informasi mengenai peraturan Qanun Aceh khususnya tentang Kepariwisataan ini yaitu Nomor 8 Tahun 2013, kami sampaikan secara sistematis melalui berbagai upaya saat sosialisasi dan informasi ini juga kami salurkan melalui teknik penyampaian secara linier pada tingkatan bagian dan jenjang yang ada di struktur organisasi di Disporapar Kota Lhokseumawe. Informasi yang kami salurkan disampaikan oleh atasan pada bagian masingmasing dan diteruskan ke bagian perangkat yang ada di bagian tersebut, dengan harapan pada saat pelaksanaan kebijakan tersebut berjalan lancar sesuai dengan ketentuan kebijakan.” (Ismail, S.Sos, Disporapar Kota Lhokseumawe, 22/06/2019)

Pelaksanaan kebijakan diawali dengan penyampaian informasi secara sistematis untuk memberikan pedoman kepada pegawai mengenai aturan dan ketentuan-ketentuan yang terdapat dalam sebuah kebijakan. Namun salah seorang pegiat pariwisata Kota Lhokseumawe mengatakan:

“... Informasi yang kami dapat dari dinas terkait masih minim dikarenakan Disporapar Kota Lhokseumawe sendiri belum memberikan informasi pariwisata secara update dan media yang digunakan juga minim seperti hanya website dan instagram... itu pun instagram duta wisatanya yang kami lihat, sedangakn media sosial dinas, kami lihat sangat pasif... dengan kemajuan ilmu teknologi saat ini sistem pemberian informasi secara digitalisasi sangat diperlukan... hal tersebut terutama dalam proses penginformasian mengenai segala kegiatan kepariwisataan." (Ulli, Kota Lhokseumawe, 20/06/2019)

Dari hasil wawancara di atas dapat dideskripsikan bahwa suatu informasi dengan kemajuan zaman saat ini sangat dibutuhkan sebab banyak orang mencari informasi termasuk tentang pariwisata dari media digital ini. Namun informasi pun harus selalu update agar calon konsumen selalu menerima informasi terkini tentang pariwisata di Kota Lhokseumawe. Keberhasilan penyampaian informasi juga berhubungan dengan suatu bentuk kewenangan. Hal ini diungkapkan oleh Kepala Disporapar Kota Lhokseumawe:

“... Dengan adanya bentuk kewenangan dari masing-masing pemangku jabatan di setiap bagian kami dapat dengan mudah melihat bagaimana bentuk implementasinya... apakah sesuai atau tidak dengan adanya kewenangan ini... kami dapat mengontrol informasi yang disalurkan dan melihat bagaimana implementasi peraturan tersebut serta melihat apakah umpan balik mengenai hal-hal tertentu kurang dipahami, seperti mengenai informasi yang berhubungan dengan pelaksanaan peraturan Qanun Aceh Nomor 8 Tahun 2013." (Zulkifli, M.Pd, Disporapar Kota Lhokseumawe, 21/06/2019) 
Dari hasil kutipan wawancara di atas dapat dipahami bahwa informasi memiliki peran penting dalam proses pelaksanaan sebuah kebijakan. Informasi yang disalurkan Disporapar Kota Lhokseumawe dilaksanakan secara linier agar dapat melihat sejauh mana informasi tersebut dapat diserap dan dipahami oleh pelaksana kebijakan. Kelancaran informasi ini juga sangat berkaitan dengan kewenangan yang ada dalam sebuah instansi. Kewenangan berperan penting dalam proses penyampaian informasi dan berguna untuk menjamin bahwa kebijakan yang dilaksanakan di Disporapar Kota Lhokseumawe sesuai dengan informasi dan isi sebuah kebijakan sehingga dapat dipastikan terlaksana berdasarkan aturan-aturan yang tertulis dalam kebijakan tersebut.

\section{f. Disposisi}

Disposisi memiliki peran penting dalam kelancaran pelaksanaan sebuah kebijakan. Peran disposisi berupa sikap dan tindak lanjut dari kebijakan serta turunan yang diteruskan kembali terhadap seluruh pegawai di suatu instansi. Hal ini menjadi salah satu faktor penunjang keberhasilan suatu kebijakan. Kepala Disporapar Kota Lhokseumawe menanggapi peran disposisi sebagaimana petikan wawancara berikut:

“.... Selaku pimpinan di Disporapar Kota Lhokseumawe saya memiliki kewajiban khusus dalam memberikan disposisi terhadap berbagai hal yang masuk ke dalam Disporapar, termasuk terhadap sebuah kebijakan mengenai kepariwisataan yang harus diterapkan kepada pegawai yang ada di Disporapar bagian pariwisata yang merupakan tindak lanjut dari sebuah kebijakan. Peran disposisi memang sangat penting dan krusial karena disposisi yang saya berikan apabila berlawanan dengan teknis yang terdapat dalam kebijakan tersebut maka ini akan mengakibatkan ketidaksesuaian yang sesungguhnya dengan implementasi di lapangan.” (Zulkifli, M.Pd, Disporapar Kota Lhokseumawe, 21/06/2019)

Dari kutipan di atas dapat diambil sebuah pemahaman bahwa disposisi memiki peran yang sangat penting dalam pelaksanaan sebuah kebijakan. Dengan adanya disposisi, sebuah kebijakan dilaksanakan berdasarkan spesialisasi setiap bagian yang berwenang yang mempunyai kapasitas sesuai dengan kebijakan. Disposisi mengenai kebijakan yang berkaitan dengan kepariwisataan di

Disporapar Kota Lhokseumawe disesuaikan dengan bidang yang terkait dan teknis pelaksanaan kebijakannya agar sesuai dengan aturan yang berlaku.

\section{g. Struktur Birokrasi}

Struktur birokrasi memiliki peranan penting dalam implementasi sebuah kebijakan. Peranan itu biasa diterjemahkan dalam pola pembagian tugas dan pola yang terkendali. Sehubungan dengan hal ini, Kepala Disporapar Kota Lhokseumawe mengatakan: 
“... Struktur birokrasi di kantor Disporapar Kota Lhokseumawe ini disusun secara sistematis yang bertujuan agar sebuah kegiatan dapat dilaksanakan dengan baik. Dengan melihat kinerja dari setiap unsur birokrasi kita dapat melihat sejauh mana sebuah tugas sudah dilaksanakan.” (Zulkifli, M.Pd, Disporapar Kota Lhokseumawe, 21/06/2019)

\section{Pembahasan}

Kebijakan pemerintah dalam rangka menciptakan lingkungan sadar wisata dalam penerapan digital tourism oleh Disporapar Kota Lhokseumawe dan masyarakat memang sampai saat ini belum dapat berjalan optimal seperti seharusnya. Kota Lhokseumawe yang memiliki banyak potensi dan daya tarik pariwisata, baik dilihat dari panorama maupun wisata kulinernya, tentunya harus dimaksimalkan dengan penerapan digital tourism. Kebijakan ini diyakini mendukung promosi pariwisata yang lebih optimal karena akses yang lebih mudah dan sangat efektif dalam menjangkau masyarakat dengan cakupan yang lebih luas.

Kebijakan promosi pariwisata di daerah sudah tertera dalam Undang-Undang Nomor 10 Tahun 2009 Pasal 6 poin (f) tentang daerah yang memiliki kewenangan untuk memfasilitasi dan melakukan promosi destinasi pariwisata dan produk pariwisata di daerahnya. Termasuk promosi secara digitalisasi dalam rangka penerapan digital tourism pun sudah seharusnya secara perlahan dipersiapkan agar promosi pariwisata di daerah dapat berjalan dengan baik. Menerapkan lingkungan sadar wisata dan mampu menerapkan promosi secara digitalisasi pada semua elemen pelaku pariwisata sudah menjadi kebutuhan dalam rangka mengikuti perkembangan zaman yang semakin serba digital. Kebijakan yang dikeluarkan oleh Pemerintah Kota Lhokseumawe yang mengacu pada Qanun Aceh Nomor 8 Tahun 2013 tentang Kepariwisataan adalah salah satu upaya agar setiap kegiatan pariwisata tidak lepas dari regulasi yang telah ditetapkan, termasuk perihal promosi pariwisata di daerah. Untuk penerapan digital tourism dan promosi pariwisata secara digitalisasi Pemerintah Kota Lhokseumawe melalui Dinas Pemuda, Olahraga, dan Pariwisata sudah mulai menerapkan hal tersebut secara perlahan meski belum optimal karena keterbatasan yang ada. Pemerintah juga sudah mengajak semua elemen pelaku pariwisata berdasarkan kebijakan yang ada. Namun pemerintah masih memerlukan program yang bersifat kreatif dan inovatif dalam rangka mendongkrak popularitas kepariwisataan di Kota Lhokseumawe.

Sosialisasi kepada masyarakat adalah kebijakan dari Disporapar Kota Lhokseumawe dalam meningkatkan kesadaran masyarakat akan manfaat dari pariwisata dan melihat bahwa sektor pariwisata sangat berpeluang membantu perekonomian masyarakat. Sosialisasi memang sangat dibutuhkan dalam proses pelaksanaan suatu kebijakan karena dalam melaksanakan kebijakan dibutuhkan kerjasama dari berbagai pihak baik itu pemerintah, pihak swasta, dan masyarakat. 
Kesadaran stakeholder diharapkan melahirkan dukungan dari semua pihak demi kesejahteraan yang akan diperoleh masyarakat apabila proses kebijakan ini berjalan dengan baik.

Keberhasilan sebuah kebijakan juga ditentukan oleh sistem komunikasi yang dibangun (Dunn, 2003). Pelaksana kebijakan harus mengetahui betul apa yang dilakukannya. Selain itu, kelompok sasaran kebijakan juga harus diinformasikan mengenai apa yang menjadi tujuan dan sasaran kebijakan. Penyaluran komunikasi yang baik akan dapat menghasilkan suatu implementasi yang baik pula. Namun seringkali terjadi masalah dalam penyaluran komunikasi yaitu adanya salah pengertian (miskomunikasi) yang disebabkan banyaknya tingkatan birokrasi yang harus dilalui dalam proses komunikasi, sehingga apa yang diharapkan terhenti dalam pelaksanannya. Dalam hal pelaksanaan sebuah kebijakan tanpa adanya proses komunikasi yang baik dan efektif dirasa hampir mustahil mendapatkan tujuan dari sebuah kebijakan seperti halnya yang terjadi pada saat ini. Penerapan digital tourism dan promosi pariwisata belum berjalan dengan optimal di Kota Lhokseumawe. Dalam hal ini diperlukan komunikasi yang baik sehingga tujuan dari sebuah kebijakan dapat tercapai.

Penyampaian informasi mengenai pelaksanaan kebijakan melalui proses komunikasi yang bersifat top dwon akan memberikan hasil yang efektif terhadap pelaksanaan kebijakan. Namun dalam proses komunikasi semacam ini juga harus diperhatikan bagaimana struktur birokrasi dalam sebuah instansi. Struktur birokrasi yang terlalu lebar tentunya akan membawa pengaruh negatif terhadap penyampaian informasi mengenai pelaksanaan suatu kebijakan. Maka dari itu instansi Disporapar Kota Lhokseumawe harus lebih optimal dalam proses pelaksanaan komunikasi, terutama yang berisi informasi mengenai teknis pelaksanaan promosi secara digitalisasi dengan semua elemen yang ada, baik pemerintah itu sediri, pihak swasta, dan tentunya masyarakat.

Pelaksanaan setiap kebijakan publik tidak pernah terlepas dari peran sumber daya. Ketersediaan sumberdaya membuat pelaksanaan suatu kebijakan publik dapat efektif. Dalam hal pelaksanaan Qanun Nomor 8 Tahun 2013 tentang Kepariwisataan instansi Disporapar Kota Lhokseumawe juga menggunakan beberapa faktor sumber daya dalam mendukung pelaksanaan kebijakan ini, di antaranya :

a. Sumber daya manusia. Kualitas sumber daya tidak terlepas dari pembekalan, pelatihan, dan pengembangan yang berhubungan dengan mekanisme sebuah kebijakan. Kekurangankekurangan yang kerap dijumpai pada sumber daya manusia yang ada diharapkan mampu diminimalisir dengan berbagai bentuk pelatihan yang diberikan sehingga tercipta sumber daya manusia yang berkualitas yang mampu menjadi faktor pendukung dalam pelaksanaan suatu kebijakan.

93 | Jurnal Ilmu Sosial dan Ilmu Politik Malikussaleh (JSPM) Volume 1 Nomor 1 Tahun 2020 
b. Anggaran. Anggaran sangat mempengaruhi efektifitas pelaksanan sebuah kebijakan sehingga dapat menjamin pencapaian terhadap sasaran dan tujuan sebuah kebijakan. Dengan adanya anggaran dalam proses pelaksanaan sebuah kebijakan maka pelaksanaan kebijakan tersebut diharapkan mampu terealisasi dengan baik serta sasaran dan tujuan kebijakan dapat tercapai.

c. Fasilitas. Ketersediaan fasilitas terutama terhadap sarana dan prasarana pelaksanaan suatu kebijakan perlu ditimbang dengan baik karena hal ini berhubungan dengan optimalisasi sebuah kebijakan. Fasilitas dalam melaksanakan penerapan digital tourism dan promosi secara digitalisasi di Disporapar Kota Lhokseumawe masih berupa akses internet, perangkat komputer, dan fasilitas lain yang mendukung kegiatan.

Kebijakan merupakan suatu bentuk konsep atau pedoman dalam berbagai keputusan sangat dipengaruhi oleh proses implementasi kebijakan. Implementasi kebijakan merupakan proses pelaksanaan kebijakan dalam rangka mewujudkan tujuan dari kebijakan. Proses implementasi sendiri juga dipengaruhi oleh beberapa faktor, salah satunya ialah faktor disposisi. Dalam pelaksanaan kebijakan, fungsi disposisi ini merupakan sikap dan tindak lanjut yang sangat bergantung kepada pemimpin dalam instansi Disporapar Kota Lhokseumawe. Sementara tiap bagian mempunyai wewenang dalam memberikan disposisi dalam hal menyesuaikan pihak mana yang mempunyai kapasitas dalam melaksanakan disposisi sebagai tidak lanjut Qanun Nomor 8 Tahun 2013 tentang Kepariwisataan. Kerjasama yang baik antara pemberi disposisi dengan pihak yang menerima disposisi memberikan pengaruh yang signifikan terhadap keberhasilan pelaksanaan suatu kebijakan. Dengan adanya disposisi ini, diharapkan kebijakan dapat terlaksana dengan baik melalui bagian yang berkompeten yang diberikan disposisi sehingga tujuan kebijakan dapat dicapai.

Struktur birokrasi merupakan hal yang berpengaruh dalam implementasi kebijakan yang mempunyai kepentingan yang berbeda-beda dalam setiap hierarkinya. Oleh karena itu struktur birokrasi secara keseluruhan memiliki peran penting dalam pelaksanaan suatu kebijakan. Struktur birokrasi pada dasarnya disusun secara sistematis dengan tujuan agar pelaksanaan suatu kebijakan dapat terlaksana dan secara efektif dan efisien sehingga tujuan dari kebijakan tersebut dapat tercapai dengan baik. Dalam pelaksanaan Peraturan Qanun Nomor 8 Tahun 2013 tentang Kepariwisataan, instansi Disporapar Kota Lhokseumawe dalam hal ini harus lebih memperhatikan peran dari struktur birokrasi yang terdapat dalam instansinya. Dalam menjalankan tugasnya pegawai harus desertai dengan standar operasional prosedur yang berfungsi sebagai pedoman yang mengikat setiap pegawai dalam melaksanakan tugasnya agar tidak keluar dari ketentuan-ketentuan dari kebijakan demi tercapainya tujuan dari kebijakan tersebut.

94 | Jurnal Ilmu Sosial dan Ilmu Politik Malikussaleh (JSPM) Volume 1 Nomor 1 Tahun 2020 


\section{KESIMPULAN}

Penerapan promosi pariwisata secara digitalisasi menjadi salah satu kunci penting untuk keberhasilan dalam upaya meningkatkan angka kunjungan wisatawan di suatu objek wisata. Dengan optimalisasi promosi pariwisata secara digital tourism, semua potensi yang dimiliki suatu daerah tujuan wisata dapat diketahui masyarakat luas dan dapat menggenjot pembangunan sektor pariwisata di daerah tersebut.

Dalam mengembangkan destinasi wisata, Pemerintah harus mampu menggandeng pihakpihak terkait seperti stakeholder, masyarakat, kelompok sadar wisata, bahkan para komunitas pegiat media sosial. Perkembangan media sosial yang begitu pesat dalam menyebarkan berbagai informasi harus bisa ditangkap sebagai peluang dalam mempromosikan wisata di Kota Lhokseumawe. Bergesernya model interaksi dari ranah "offline ke online" merupakan sebuah keharusan untuk menggencarkan promosi menggunakan digital tourism. Pemanfaatan teknologi masa kini dilakukan juga dengan mendorong partisipasi masyarakat setempat untuk ikut menjadi bagian dari tim promosi. Menggandeng pegiat media digital dan menjadikan mereka mitra kerja tentunya akan memudahkan usaha Pemerintah Daerah dalam melakukan publikasi dan pemasaran wisata di Kota Lhokseumawe.

Optimalisasi penerapan digital tourism dapat diwujudkan dengan memberikan kesempatan kepada masyarakat terutama anak muda Kota Lhokseumawe untuk membantu dalam mempromosikan pariwisata di Kota Lhokseumawe dan memberikan pelatihan softskill terkait wawasan dan keterampilan pihak internal Disporapar dalam mengelola promosi pariwisata berbasis digital di Kota Lhokseumawe. Pemerintah daerah dan pelaku bisnis pariwisata kiranya perlu konsisten memanfaatkan media dan teknologi informasi sebagai sarana promosi kepada seluruh calon wisatawan dan pemangku kepentingan lainnya sehingga terbangun sistem informasi wisata Kota Lhokseumawe yang terintegrasi. Merancang dan mengembangkan sistem informasi wisata yang lengkap, update, dan interaktif akan membantu pengembangan sektor pariwisata secara lebih efektif dan efisien.

\section{DAFTAR PUSTAKA}

Agustino, L. (2012). Dasar-Dasar Kebijakan Publik. Alfabeta.

Dunn, W. N. (2003). Pengantar Analisis Kebijakan Publik. Gadjah Mada University Press.

Hadinoto, K. (1996). Perencanaan Pengembangan Destinasi Pariwisata. UI-Press.

95 | Jurnal Ilmu Sosial dan Ilmu Politik Malikussaleh (JSPM) Volume 1 Nomor 1 Tahun 2020 
Hasan, M. I. (2001). Pokok-Pokok Materi Statistik I (Statistik Deskriptif). Bumi Aksara.

Isnaini, N. L. \& Fauziyyah, S. (2017). Peran Digital Marketing terhadap Brand Equity Produk Pariwisata. Snaper-Ebis, 406-410.

Nugroho, R. (2014). Public Policy. PT. Elex Media Komputindo.

Nurhidayati, S. E. \& Fandeli, C. (2012). Penerapan Prinsip Community Based Tourism (CBT) dalam Pengembangan Agrowisata di Kota Batu Jawa Timur. Jurnal Administrasi Publik, $4(1)$.

Pitana, I. G. \& Diarta, I. K. S. (2009). Pengantar Ilmu Pariwisata. Andi.

Prihati (2017). Implementasi Kebijakan Promosi Pariwisata Kota Pekanbaru dalam Pengembangan Potensi Wisata di Provinsi Riau. Disertasi. Universitas Pasundan.

Puspawati, D. P. H. \& Ristanto (2018). Strategi Promosi Digital untuk Pengembangan Pariwisata Kota Magelang. Jurnal Jendela Inovasi Daerah, 1(2), 1-20.

Qanun Aceh No 8 Tahun 2013 tentang Kepariwisataan.

Ri'aeni, I. (2015). Penggunaan New Media dalam Promosi Pariwisata Daerah Situs Cagar Budaya di Indonesia. Jurnal Komunikasi, 9(2), 187-197.

Sugiyono (2009). Metode Penelitian Kuantitatif, Kualitatif, dan R\&D. Alfabeta.

Supratman, L. P. (2018). Penggunaan Media Sosial oleh Digital Native. Jurnal Ilmu Komunikasi, $15(1), 47-60$.

Umar, H. (2014). Metode Penelitian untuk Skripsi dan Tesis Bisnis. Rajawali Pers.

Undang-Undang Republik Indonesia Nomor 10 Tahun 2009 tentang Kepariwisataan

Usman \& Nurdin. (2002). Konteks Implementasi Berbasis Kurikulum. PT. RajaGrafindo Persada.

Wicaksono, M. S. \& Yunitasari, D. (2018). Efektivitas Endorser dalam Promosi Pariwisata Indonesia. Jurnal Gama Societa, 1(1), 1-8.

96 | Jurnal Ilmu Sosial dan Ilmu Politik Malikussaleh (JSPM) Volume 1 Nomor 1 Tahun 2020 